disease? Even if we accept that then the psychosocial stresses of adolescence contribute at least as much as physiology to poor control.

Brittle became a convenient word for parents, nurses, and doctors struggling to cope with difficult metabolic control in their charges. Brittle diabetes does exist -in the sense that some young (and some not so young) patients with poorly controlled diabetes do experience very unstable glycaemic control. And specific abnormalities - for example, of insulin absorption - have been found. ${ }^{7}$ But the term has become inextricably associated with cases of manipulative behaviour and carries pejorative overtones. Our increased understanding of the metabolic causes of diabetic instability and the contribution of psychological stress to erratic glycaemic control gives us new, more specific, diagnostic labels.

The follow up studies lead to the conclusion that brittle diabetes may be self limiting and not intrinsically different from non-brittle diabetes in the long term. The main risk to life is recurrent hypoglycaemia, which may be a separate syndrome. Any psychosocial difficulties need treatment. Deciding how to use expensive and potentially dangerous treatments is not easy. Indeed, the effect of the intensive regimens used for brittleness has not been examinedoutcome might have been different without them. Regardless of their label, patients with unstable diabetes need expert multidisciplinary care.

Senior Lecturer, Unit for Metabolic Medical Medicine Division of Medicine, United Medical and Dental Schools, Guy's Hospital, London SE1 9RT.
Woodyatt RT. Diabetes mellitus. In: Cecil RL, ed. A textbook of medicine. 3rd ed. Philadelphia WB Saunders, 1934:628.

Tattersall R. Brittle diabetes. Clin Endocrinol Metab 1977;6:403-19.

Paulsen EP, Courtney JW, Duckworth WC. Insulin resistance caused by massive degradation of subcutaneous insulin. Diabetes 1979;28:640-5.

4 Williams G, Pickup J, Clark A, Bowock S, Cooke E, Keen H. Changes in blood flow close to subcutaneous insulin injection sites in stable and brittle diabetics. Diabetes 1983;32:466-73.

Williams G, Pickup JC, Keen H. Massive insulin resistance apparently due to rapid clearance of circulating insulin. Am $\mathcal{F}$ Med 1987;82:1247-52.

6 Schade DS, Duckworth WC. In search of the subcutaneous insulin resistance syndrome. $N$ Engl f Med 1986;315:147-53.

Williams G, Pickup JC. Continuous intravenous insulin infusion in patients unresponsive to subcutaneous insulin. In: Pickup JC, ed. Britle diabetes. Oxford: Blackwell Scientific Publications, 1985:262-74.

8 Schade DS, Eaton RP. Intraperitoneal insulin administration in brittle diabetes. In: Pickup JC, ed. Brittle diabetes. Oxford: Blackwell Scientific Publications, 1985:275-88.

Williams G, Pickup JC. The natural history of brittle diabetes. Diabetes Res 1988;7:13-8.

10 Pickup JC, Williams G, Johns $P$, Keen $\mathrm{H}$. Clinical features of brittle diabetic patients unresponsive to optimized subcutaneous insulin therapy. Diabetes Care 1983;6:279-284.

11 Tattersall R, Walford S. Brittle diabetes in response to life-stress: "Cheating and manipulation." In: Pickup JC, ed. Brittle diabetes. Oxford: Blackwell Scientific Publications, 1985:76-101.

12 Stancin T, Luih DL, Reuter JM. Binge eating and purging in young women with IDDM. Diabetes Care 1989;12:601-3.
Canc Tuih DL, Reut

13 Tattersall R, Gregory R, Selby C, Kerr D, Heller S. Course of brittle diabetes: 12 year follow up. BMF 1991;302:1240-3.

14 Gill GV, Alberti KGMM. Outcome of brittle diabetes. BMF 1991;303:285-6.

15 Amiel SA, Tamborlane WV, Simonson DC, Sherwin RS. Defective glucose counterregulation after strict control of insulin dependent diabetes mellitus. N Engl f Med 1987;316:1376-83.

16 Ryder RJ, Owens DR, Hayes TM, Ghatei MA, Bloom SR. Unawareness of hypoglycaemia and adequate hypoglycaemic counterregulation: no causal relationship with diabetic autonomic neuropathy. BMF 1990;301:783-7.

17 Heller SR, Cryer PE. An antecedent episode of hypoglycemia reduced neuroendocrine and symptomatic responses to subsequent hypoglycemia in normal humans. Diabetes. In press.

8 Lager I, Atvall S, Eriksson BM, Von Schenk H, Smith U. Studies on the insulin antagonistic effect of catecholamines in normal man. Diabetologia 1986;29:409-16.

19 Lager $\mathrm{GH}$, Kollind $\mathrm{M}$, Adamson U, Lins PE. Importance of growth hormone for blood glucose regulation following insulin induced nocturnal hypoglycemia in insulin dependent diabetes mellitus. Acta Med Scand 1988;223:159-64.

20 Amiel SA, Simonson DC, Sherwin RS, Lauritano AA, Tamborlane WV. Exaggerated epinephrine responses to hypoglycemia. I Pediatr 1987;110:832-7.

21 Amiel SA, Sherwin RS, Simonson DC, Lauritano AA, Tamborlane WV. Impaired insulin action in puberty: a contributing factor to poor glycemic control in adolescents with diabetes. $N$ Engl $f$ Med 1986;315:215-9.

22 Rosenbloom AL, Clarke DW. Excessive insulin treatment and the Somogyi effect. In: Pickup JC, ed. Brittle diabetes. Oxford: Blackwell Scientific Publications, 1985:103-31.

\title{
What do patients want?
}

\section{Someone who will hear their questions}

Patients consult doctors because they want help with their illnesses. Writing in 1935, Brackenbury interpreted this as meaning that patients wanted clinical competence; unable to judge this for themselves, they had to rely on the professional integrity of doctors. ${ }^{1}$ For many years doctors have regarded patients as relatively passive, but this has begun to change.

Researchers drawn from both medicine and the social sciences first noticed the change in the years after the second world war when they began to inquire beyond the presenting symptom to the patient's view of health, illness, and medical care. ${ }^{2}$ The finding that most people who became ill chose not to visit their doctor ${ }^{3}$ and reports of patients' low rates of adherence to medical advice and treatment ${ }^{4}$ undermined the assumption that illness was taken to the doctor for clinical help. Patients seemingly wanted something more. Surveys of patients' views identified one recurrent complaint: doctors rarely provided sufficient information about their medical problems,${ }^{56}$ and, for a time, competent clinical care, courtesy, and adequate information summed up what patients wanted.

Over the past decade, however, what patients want has undergone a fundamental reappraisal. The cornerstone of professional practice has always been that, though patients might know what they wanted, doctors (through their specialised knowledge) knew what they needed. Emphasis on good clinical care and information giving still reflects medical definitions of what is needed; the major shift has been an increasing recognition that patients' wants are not capricious whims but needs in themselves. Explanation and understanding, as well as emotional support, have now been added to medical treatment and information as the main things that patients want from their doctors. ${ }^{8}$

Intensive studies of patients' perceptions of illness have discovered that patients hold elaborate and often sophisticated theories of their own illness. ${ }^{9}$ In essence patients seem to need answers to three basic questions about their illness: "Why me?" "Why now?" and "Why this (particular illness)?"10 They seek information that helps to answer these questions in a form that makes sense to them; indeed, some visits to the doctor may be made expressly for this purpose.

Recent work on the ways patients cope has confirmed the importance of widely differing desires for information. Patients have been divided into those who search for and demand more information about their problem ("monitors") and those who deliberately avoid information, especially that which might have negative connotations ("blunters"). ${ }^{1 "}$ Thus patients who complain about the lack of information may paradoxically be the best informed.

At least some of this reassessment of what patients want can be explained by the growth of consumerism and the belief that the rights of the consumer are sovereign. This movement is evident in the recent NHS reforms, which have created-at least as part of the rhetoric-more of a market place for health care, in which consumers' wishes can be better accommodated. Further evidence for the greater attention given to what patients want is the growth of routine surveys of patients' satisfaction and more formal studies of patients' views of medical care ( $\mathrm{p} 289){ }^{12}$

What are the limits of this new consumerist medicine? Patients need protection from the dangers inherent in much medical investigation, diagnosis, and treatment and for the 
foreseeable future must continue to rely on medical preeminence in these areas. Moreover, many patients' needs, such as emotional support, may not be consciously formulated as wants. And providing a service more responsive to patients' demands clearly has considerable implications for resources.

Ironically, just as a consumerist perspective begins to develop there has been an increase in consultations initiated by the doctor (such as those for health promotion), in which doctors' definitions of need take precedence over patients' overt wants. Some surveys suggest that patients do not mind this approach, ${ }^{13}$ but more detailed work suggests many qualifications to this apparent mandate for medicine once again to take the initiative in defining need. ${ }^{1+}$

Reflecting on the doctor-patient relationship over 50 years ago, Cassidy suggested that the only thing that doctors wanted to hear from their patients was "an account of their symptoms, as concise as possible and chronological."'15 This view stands in complete opposition to what patients report as what they most value: a doctor who listens ${ }^{16}$-if only to begin to appreciate what the patient wants. And though it would seem that listening is a medical skill more valued than previously, this does not necessarily mean that doctors have yet learnt always to hear what patients are saying.

Reader in Sociology as Applied to Medicine,

DAVID ARMSTRONG

United Medical and Dental Schools of Guy's and St Thomas's Hospitals,

London SE1 9RT

Brackenbury HB. Patient and doctor. London: Hodder and Stoughton, 1935

Armstrong D. The patient's view. Soc Sci Med 1984;18:737-44.

Mechanic D. The concept of illness behaviour. Fournal of Chronic Diseases 1962:15:189-94.

4 Ley P. Towards better doctor-patient communications. In: Bennett AE, ed. Communcation between doctors and patients. Oxford: Oxford University Press, 1976:75-98.

5 Cartwright A. Human relations and hospital care. London: Routledge and Kegan Paul, 1962

6 Gregory J. Patients' attitudes to the hospital service. London: HMSO, 1978.

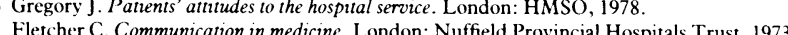

8 Salmon P, Quine J. Patients intentions in primary care: measurement and preliminary investigation. Psychology and Health $1989 \cdot 3: 103-10$.
.

9 Tuckett D, Boulton M, Olson C, Williams A. Meetings berween experts: an approach to sharing idea in medical consultations. London: Tavistock, 1985 .

10 Kleinman A, Eisenberg L, Good B. Culture, illness and cure. Ann Intern Med 1978;88:251-9.

11 Miller SM, Brody DS, Summerton J. Styles of coping with threat: implications for health. f Pers Soc Psychol 1988;54:142-8.

12 Martin E, Russell D, Goodwin S, Chapman R, North M, Sheridan M. Why patients consult and what happens when they do. BMF 1991;303:289-92.

13 Wallace P, Brennan PJ, Haines A. Are general practitioners doing enough to promote healthy lifestyle? BMJ 1987;294:940-2.

14 Stott NCH, Pill RM. Advise yes, dictate no. Patients' views on health promotion in the consultation. Fam Pract 1990; 7:125-31

15 Cassidy $M$. Doctor and patient. Lancet 1938;i:175-9.

16 Smith C, Armstrong D. Comparisons of criteria derived by governments for evaluating general practitioner services. BMF 1989;299:494-6.

\section{Total knee replacement}

\section{Getting better all the time}

With operations for knee arthroplasty increasing faster than those for total hip replacement some of the British scepticism about knee surgery is clearly disappearing. Recent studies justify this change of attitude: in experienced units the insertion of condylar prostheses in well selected cases probably has a higher success rate than that for total hip replacement and gives rise to fewer long term complications and failures. ${ }^{12}$

The operation's success depends on the selection of patients, choice of prosthesis, and surgical skill. Patients should be judged on their symptoms rather than their radiological signs; the correlation between the two may be poor. Provided they are fit enough for surgery patients with pain at rest and disturbed sleep should be offered operation. Those whose pain on movement confines them to their home and garden should also be considered. The operation relieves pain in more than $95 \%$ of cases, ${ }^{23}$ with functional improvement occurring in over $90 \% .^{3+}$ Patients with rheumatoid arthritis do particularly well. ${ }^{3}$

Some doctors would exclude anyone under 60 from the operation, but that could mean confining young adults to wheelchairs for years until they had "earned" their operation. Failure rates for mostly now obsolete designs have exceeded $20 \%$ at 10 years, ${ }^{5}$ but the original total condylar knee replacement has a survivorship a little in excess of $90 \%$ at 15 years, a reassuring prospect for the 35 year old rheumatoid patient, confined to a wheel chair. The posterior stabilised derivative of the total condylar replacement has a $97 \%$ survivorship at 10 years. Thus for the younger patient the possibility of subsequent failure and need for revision is probably less than it is for hip replacement.

Deciding whether to operate on the active, usually overweight, and often male patient with an osteoarthritic knee is more difficult. Claims of "absolute agony" after a spirited descent of Snowdon should be taken circumspectly, especially if proposals for losing weight, physiotherapy, and buying a walking stick are regarded with disdain. Such patients need to know that although surgery produces excellent results knee arthroplasties are most vulnerable in those who wish to dance or walk up or ski down mountains. These patients have to understand the consequences of fractures and dislocations (both very rare), late infection, and, above all, wear and loosening.

As with other major operations complications may occur at the time of surgery. Technical problems such as neurovascular disorders and perioperative fractures should be avoidable. Rarely infection and thromboembolism (despite prophylaxis) occur, with disastrous results.

What prosthesis should be used? Few knees, however deformed or unstable, cannot be successfully replaced with a prosthesis with a total condylar type of resurfacing. ${ }^{14}$ This has superseded prostheses depending on hinges,${ }^{68}$ long stems in medullary cavities,,${ }^{7.9}$ small stress bearing areas, ${ }^{10}$ and major sacrifices of bone stock. ${ }^{8}$ These should no longer be routinely used: not only are complications and survival of the joint worse but surgical options are limited if further operations are needed. ${ }^{6}$ Unfortunately, some orthopaedic surgeons continue to use them, justifying the doubts that some people hold about the operation.

Lastly, there is the question of surgical skill. With increasing subspecialisation in orthopaedics the time for occasional knee replacements performed in non-specialist units may soon be over.

JONATHAN NOBLE Consultant Orthopaedic Surgeon ROY C HILTON

Hope Hospital,

Salford M6 8HD

1 Insall JN. Total knee replacement. In: Insall JN, ed. Surgery of the knee. New York: Churchill

Livingstone, 1984:587-695.
2 Ranawat CS, Boachie-Adjei O. Survivorship analysis and results of total condylar knee arthroplasty; 8-11 year follow-up period. Clin Orthop 1988;226:6-13.
and

3 Noble J, Hodgkinson JP, Brabu KJ, Potts H. The total condylar knee replacement: a robust and Noble J, Hodgkinson JP, Brabu KJ, Potts $\mathrm{H}$. The total condylar knee replacement: a robust and
reliable prosthesis. In: Noble J, Galasko CSB, eds. Recent developments in orthopaedic surgery. Manchester: Manchester University Press, 1987:274-82.

4 Vince KG, Insall JN, Kelly MA. The total condylar prosthesis. 10-12 year results of the cemented knee replacement. F Bone foint Surg [Br] 1989;71:793-7.

5 Scuderi GR, Insall JN, Windsor RE, Moran MC. Survivorship of cemented knee replacements. f Bone foint Surg [Br] 1989;71:798-803.

6 Noble J. Total knee replacement - not a bridge too far. F Bone foint Surg [Br] 1990;72:173-4.

7 Stulberg SD. Arthrodesis in failed total knee replacements. Orthop Clin North Am 1982;13:213-24. 8 Simison AJM, Noble J, Hardings K. Complications of the Attenborough knee replacement. $\mathcal{F}$ Bon foint Surg [Br] 1986;68: 100-4.

Tew $M$, Waugh W, Forster IW. Comparing the results of different types of knee replacement. J Bone foint Surg $[\mathrm{Br}]$ 1985;67:775-9.

10 Barlin CE, Jankin I. A 5-8 year follow up of the Sheehan total knee arthroplasty. $f$ Bone foint Surg $[B r]$ 1987;69:680. 